\title{
ANALISIS PERSEPSI PETANI TERHADAP PUPUK ORGANIK DI KECAMATAN WALENRANG UTARA KABUPATEN LUWU UTARA
}

\author{
Intisari*1) $^{* 1}$, Srida Mitra Ayu ${ }^{2)}$, Rosnina ${ }^{1)}$, Dewi Marwati Nuryanti ${ }^{1)}$ \\ ${ }^{1)}$ Program Studi Agribisnis Fakultas Pertanian, Universitas Andi Djemma Palopo \\ ${ }^{2)}$ Program Studi Kehutanan Fakultas Kehutanan, Universitas Andi Djemma Palopo \\ *)e-mail : intisarilatief@gmail.com
}

\section{Ringkasan}

Persepsi dapat mempengaruhi petani dalam mengambil keputusan pada kegiatan usahataninya. Persepsi yang keliru atau negatif terhadap suatu produk akan menyebabkan sikap yang negatif, perilaku yang kurang bagus terhadap produk tersebut dan tentunya akan mempengaruhi pada keputusan untuk menggunakan atau tidak menggunakan produk tersebut. Oleh karena itu, sangatlah penting untuk menganalisis persepsi tersebut. Penelitian ini bertujuan untuk menganalisis persepsi petani terhadap pupuk organik. Sampel dalam penelitian ini berjumlah 258 orang petani padi yang ada di Kecamatan Walenrang Utara Kabupaten Luwu. Hasil penelitian memperlihatkan bahwa persepsi petani terhadap pupuk organik adalah ramah lingkungan, tidak ada kandungan zat kimianya, harganya lebih murah, mudah di dapat, mudah di buat, produk yang dihasilkan lebih banyak di cari orang, simbol dari gaya hidup yang sehat, harga dari produk yang dihasilkan lebih mahal, hasil yang banyak dalam jangka panjang, pupuk yang dianjurkan oleh pemerintah, harga dari produk yang dihasilkan mahal, produk yang dihasilkan lebih bergengsi, pupuk yang terbuat dari kotoran hewan dan bahan alami lainnya serta tidak mengandung bahan kimia, pupuk organik terbatas produksinya dan susah didapatkan apabila dibutuhkan dalam jumlah yang banyak sekaligus. Dan tingkat persepsi petani terhadap pupuk organik adalah negatif $(35,3)$.

Kata kunci : persepsi, pupuk organik, petani padi 


\title{
ANALYSIS OF FARMERS PERCEPTION OF ORGANIC FERTILIZERS IN NORTH WALENRANG DISTRICT NORTH LUWU DISTRICT
}

\begin{abstract}
Perception can influence farmers in making decisions on farming activities. Incorrect or negative perception of a product will cause a negative attitude, bad behavior towards the product and will certainly affect the decision to use or not use the product. Therefore, it is very important to analyze this perception. This study aims to analyze farmers' perceptions of organic fertilizer. The sample in this study amounted to 258 rice farmers in North Walenrang District, Luwu Regency. The results showed that farmers' perception of organic fertilizer is environmentally friendly, there is no chemical content, the price is cheaper, easy to get, easy to make, more products are sought after by people, a symbol of a healthy lifestyle, the price of the product produced more expensive, a lot of results in the long run, fertilizer recommended by the government, the price of products produced is expensive, the products produced are more prestigious, fertilizers made from animal manure and other natural materials and do not contain chemicals, limited organic fertilizer production and difficult to obtain if needed in large quantities at once. And the level of farmers' perception of organic fertilizer is negative (35.3).
\end{abstract}

Keywords: perception, organic fertilizer, rice farmers

\section{PENDAHULUAN}

Pupuk organik memiliki kelebihan antara lain mengandung unsur hara yang lengkap, dalam hal ini unsur hara makro dan mikro; dapat memperbaiki sifat fisik, kimia dan biologi tanah sehingga dapat memperbaiki dan meningkatkan kesuburan tanah; dan lain sebagainya. Namun pupuk organik di tingkat petani permintaannya atau penggunaannya belum terlalu signifikan, karena mereka menganggap bahwa jumlah produksi sedikit jika menggunakan pupuk organik.

Banyak faktor yang menyebabkan petani bertindak dalam pemilihan pupuk yang akan digunakan dalam usahataninya, antara lain persepsi mereka terhadap suatu hal. Setiap petani memiliki persepsi mereka sendiri-sendiri terhadap pupuk organik maupun anorganik. Dan persepsi ini bisa mempengaruhi mereka untuk bersikap dan mengambil tindakan apakah menggunakan pupuk organik atau anorganik pada usahatani mereka. Persepsi ini pulalah yang dapat mendorong seseorang untuk melakukan atau memilih sesuatu, termasuk dalam pengambilan keputusan penggunaan suatu jenis pupuk.

Persepsi dapat didefinisikan sebagai suatu proses dimana individu mengorganisasikan dan memaknakan kesan-kesan indera untuk dapat memberikan arti terhadap lingkungannya. Apa yang seseorang persepsi terhadap sesuatu dapat berbeda dengan kenyataan yang objektif. Persepsi dapat mempengaruhi petani dalam mengambil keputusan pada kegiatan usahataninya. Persepsi yang keliru atau negatif terhadap suatu produk akan menyebabkan 
sikap yang negatif, perilaku yang kurang bagus terhadap produk tersebut dan tentunya akan mempengaruhi pada keputusan untuk menggunakan atau tidak menggunakan produk tersebut. Oleh karena itu, sangatlah penting untuk menganalisis persepsi tersebut. Tujuan dalam penelitian ini adalah untuk menganalisis persepsi petani terhadap pupuk organik.

\section{METODE PENELITIAN}

\section{Waktu dan Tempat}

Penelitian dilaksanakan pada Bulan April sampai Nopember 2019 di Kecamatan Walenrang Utara Kabupaten Luwu, dengan pertimbangan bahwa wilayah ini merupakan sentra pengembangan komodi padi di daerah Luwu.

\section{Sampel Penelitian}

Sampel penelitian berjumlah 258 orang petani padi di Kecamatan Walenrang Utara Kabupaten Luwu.

\section{Sumber dan Jenis Data}

Sumber data dalam penelitian yaitu petani padi dan data diperoleh dari informasi penyuluh, dinas terkait dan kepustakaan. Sedangkan jenis data yaitu data primer, yaitu data yang diperoleh langsung oleh responden, baik melalui pendekatan riset (seperti observasi, dan survei), metode kontak (seperti kontak langsung atau wawancara langsung), dan instrument riset (seperti kuisioner). Data sekunder, yaitu data yang sudah tersedia yang bersumber dari instansi-instansi terkait, guna mendukung penelitian ini seperti kantor kelurahan, instansi pemerintah lainnya, serta kepustakaan.

\section{Metode Pengumpulan Data}

Teknik pengumpulan data pada penelitian ini adalah :

1. Observasi, yaitu pengumpulan data primer dengan cara pengamatan langsung di lapangan.

2. Survei, yaitu pengumpulan data primer dengan melakukan tanya jawab dengan responden.

3. Wawancara, yaitu pengumpulan data primer dan data sekunder dengan cara mengadakan tanya jawab dengan responden.

4. Kuisioner, yaitu pengumpulan data primer dengan wawancara tertulis.

\section{Metode Analisis Data dan Interpretasi Data}

Untuk menganalisis persepsi petani terhadap pupuk organik digunakan analisis deskriptif. Data yang ada, dipersentasikan, diuraikan, sehingga dapat digambarkan persepsipersepsi petani terhadap pupuk organik. Dan tingkat persepsi diinterpretasikan dengan skala interval :

Jadi,

$$
\frac{100 \%-0 \%}{5}=20
$$

$$
\begin{aligned}
0-20 & =\text { Sangat Negatif } & 40,01-60 & =\text { Netral } \\
20,01-40 & =\text { Negatif } & 60,01-80 & =\text { Positif }
\end{aligned}
$$




\section{HASIL DAN PEMBAHASAN}

Banyak faktor yang menyebabkan petani bertindak dalam pemilihan pupuk yang akan digunakan dalam usahataninya, antara lain persepsi mereka terhadap suatu hal. Setiap petani memiliki persepsi mereka sendiri-sendiri terhadap pupuk organik maupun, dan persepsi ini bisa mempengaruhi mereka untuk bersikap dan mengambil tindakan apakah menggunakan pupuk organik pada usahatani mereka atau tidak. Persepsi ini pulalah yang dapat mendorong seseorang untuk melakukan atau memilih sesuatu, termasuk dalam pengambilan keputusan penggunaan suatu jenis pupuk. Tabel 1 menyajikan persepsi petani terhadap pupuk organik dan rata-rata tingkat persepsi petani terhadap pupuk organik di Kecamatan Walenrang Utara Kab. Luwu.

Tabel 1. Persepsi Petani dan Rata-Rata Tingkat Persepsi Petani Terhadap Pupuk Organik Di Kecamatan Walenrang Utara Kab. Luwu

\begin{tabular}{lrrl}
\hline Persepsi Petani Terhadap Pupuk Organik & $\begin{array}{r}\text { Jumlah } \\
\text { (orang) }\end{array}$ & Persentase (\%) & \multicolumn{1}{c}{$\begin{array}{c}\text { Tingkat } \\
\text { Persepsi }\end{array}$} \\
\hline Ramah lingkungan & 228 & 88,37 & Sangat Positif \\
Tidak ada kandungan zat kimianya & 235 & 91,09 & Sangat Positif \\
Harganya lebih murah & 81 & 31,40 & Negatif \\
Mudah di dapat & 77 & 29,84 & Negatif \\
Mudah di buat & 46 & 17,83 & Sangat Negatif \\
Produk yang dihasilkan lebih banyak di cari & 14 & 5,43 & Sangat Negatif \\
orang & 127 & 49,22 & Netral \\
Simbol dari gaya hidup yang sehat & 18 & 6,98 & Sangat Negatif \\
Harga dari produk yang dihasilkan lebih & 35 & 13,57 & Sangat Negatif \\
mahal & 172 & 66,67 & Positif \\
Hasil yang banyak dalam jangka panjang & 9 & 3,49 & Sangat Negatif \\
Pupuk yang dianjurkan oleh pemerintah & 5 & 1,94 & Sangat Negatif \\
Harga dari produk yang dihasilkan mahal & & & Sangat Positif \\
Produk yang dihasilkan lebih bergengsi & 207 & 80,23 & \\
.Pupuk yang terbuat dari kotoran hewan, dan & & & Sangat Negatif \\
bahan alami lainnya, tidak mengandung & 21 & 8,14 & \\
bahan kimia & & & \\
$\begin{array}{l}\text { Pupuk organik terbatas produksinya, dan } \\
\text { susah didapatkan apabila dibutuhkan dalam }\end{array}$ & 21 & 35,30 & Negatif \\
jumlah yang banyak sekaligus & & & \\
\hline Rata-Rata Tingkat Persepsi &
\end{tabular}

Sumber : Data Primer Setelah diolah, 2019

Tabel 1 menyajikan hasil tentang persepsi dan tingkat persepsi petani terhadap pupuk organik, di mana ada empat belas persepsi petani terhadap pupuk organik yaitu ramah lingkungan, tidak ada kandungan zat kimianya, harganya lebih murah, mudah di dapat, mudah 
di buat, produk yang dihasilkan lebih banyak di cari orang, simbol dari gaya hidup yang sehat, harga dari produk yang dihasilkan lebih mahal, hasil yang banyak dalam jangka panjang, pupuk yang dianjurkan oleh pemerintah, harga dari produk yang dihasilkan mahal, produk yang dihasilkan lebih bergengsi, pupuk yang terbuat dari kotoran hewan dan bahan alami lainnya serta tidak mengandung bahan kimia, pupuk organik terbatas produksinya dan susah didapatkan apabila dibutuhkan dalam jumlah yang banyak sekaligus.

Dari Tabel 1 pula terlihat bahwa tingkat persepsi petani terhadap pupuk organik adalah negatif (35,3). Hal ini disebabkan karena, dari empat belas variabel persepsi, ada tujuh variabel yang tingkat persepsinya sangat negatif, dua variabel yang tingkat persepsinya negatif, tiga variabel yang tingkat persepsinya sangat positif, satu variabel yang tingat persepsinya positif, dan satu variabel yang tingkat persepsinya netral.

Ini memperlihatkan bahwa persepsi petani terhadap pupuk organik belum terlalu baik, dalam artian petani masih menganggap bahwa pupuk organik itu susah di dapat, tidak mudah di buat, produk yang dihasilkan belum banyak di cari orang, harga dari produk yang dihasilkan sama saja dengan harga produk yang dihasilkan pupuk anorganik, harga pupuk organik mahal, pupuk organik terbatas produksinya dan susah didapatkan apabila dibutuhkan dalam jumlah yang banyak sekaligus, produk yang dihasilkan tidak lebih bergengsi dari produk an-organik, dan hasil tidak banyak dalam jangka panjang. Hal ini disebabkan pengetahuan dan pengalaman petani terhadap pupuk organik masih kurang dan cenderung negatif seperti pengalaman mereka bahwa pupuk organik padat jarang dijual di toko, dianjurkan oleh pemerintah tetapi kurang disosialisasikan, pupuk organik ini harus dibeli dan jarang dibagikan seperti pupuk an-organik.

Hal tersebut dapat menjadi perhatian pelaksana program ke depan, apakah pengembangan program atau program yang baru, untuk memberikan pemahaman secara terus menerus tentang keunggulan dan manfaat pupuk organik, sehingga informasi dan pengetahuan yang diperoleh lebih positif. Perlu adanya peningkatan sosialisasi agar petani memiliki pemahaman atau persepsi yang sama, pengetahuan yang banyak dan positif akan pupuk organik serta keunggulan-keunggulan dari pupuk organik. Dimana menurut Sumarwan (2004), bahwa pengetahuan yang baik mengenai suatu produk seringkali mendorong seseorang untuk menyukai produk tersebut. Lebih lanjut Schiffman and Kanuk (2008), mengatakan bahwa komponen kognitif terdiri dari berbagai kognisi seseorang yaitu pengetahuan dan persepsi yang diperoleh berdasarkan kombinasi pengalaman langsung dengan obyek sikap dan informasi yang berkaitan dari berbagai sumber. Dan Suryani T. (2016), mengatakan bahwa jika konsumen mempersepsikan bahwa produk kita memiliki keunggulan yang berbeda dengan produk lain dan keunggulan itu sangat berarti bagi konsumen, maka konsumen akan memilih produk kita, meskipun sebenarnya produk tersebut relatif mirip dengan yang lainnya.

\section{KESIMPULAN}

Tingkat persepsi petani terhadap pupuk organik adalah negatif $(35,3)$, yaitu ramah lingkungan, tidak ada kandungan zat kimianya, harganya lebih murah, mudah di dapat, mudah di buat, produk yang dihasilkan lebih banyak di cari orang, simbol dari gaya hidup yang sehat, harga dari produk yang dihasilkan lebih mahal, hasil yang banyak dalam jangka panjang, pupuk yang dianjurkan oleh pemerintah, harga dari produk yang dihasilkan mahal, produk 
yang dihasilkan lebih bergengsi, pupuk yang terbuat dari kotoran hewan dan bahan alami lainnya serta tidak mengandung bahan kimia, pupuk organik terbatas produksinya dan susah didapatkan apabila dibutuhkan dalam jumlah yang banyak sekaligus.

\section{DAFTAR PUSTAKA}

Basri H. 2016. Analisis Persepsi Petani Terhadap Pemanfaatan Bokashi Pada Pertanaman Padi Sawah (Farmers Perception Analysis Toward Bokashi Use On Rice Cultivation). AGRISEP Vol. 15 No. 2. hal: 135 - 142.

Hermawati U., Hanifah Ihsaniyati, Bekti Wahyu Utami. 2016. Persepsi Petani Terhadap Karakteristik Pupuk Organik Cair Limbah Etanol Di Kecamatan Mojolaban. AGRISTA Vol. 4 No. 3. hal. 1-12.

Nasir. 2008. Pengaruh Penggunaan Pupuk Bokasi pada Pertumbuhan dan Produksi Padi Palawija dan Sayuran. http://www.dispertanak.pandeglang.go.id/artikel

Sangadji E.M., Sopiah. 2013. Perilaku Konsumen (Pendekatan Praktis disertai Himpunan Jurnal Penelitian). Penerbit ANDI, Yogyakarta.

Setiadi N. 2015. Perilaku Konsumen (Perspektif Kontemporer pada Motif, Tujuan, dan Keinginan Konsumen). Edisi Revisi. Prenadamedia Group, Jakarta.

Setiadi N. 2015. Perilaku Konsumen (Konsep dan Implikasi untuk Strategi dan Penelitian Pemasaran). Prenada Media, Jakarta.

Sumarwan U. 2004. Perilaku Konsumen (Teori dan Penerapannya dalam Pemasaran). Penerbit Ghalia Indonesia, Bogor.

Suryani T. 2016. Perilaku Konsumen (Implikasi pada Strategi Pemasaran). Graha Ilmu, Yogyakarta.

Tedjaningsih T, Suyudi, dan Nuryaman H. 2017. Persepsi Petani Terhadap Penggunaan Pupuk Organik Pada Usahatani Mendong. Mimbar Agribisnis Jurnal Pemikiran Masyarakat Ilmiah Berwawasan Agribisnis. Vol. 3 No. 1. Hal. 64-72.

Thio S., Ninna Yuanita Sari Harianto, dan Ricky Ferdinand Sosiawan. 2008. Persepsi Konsumen Terhadap Makanan Organik Di Surabaya. Jurnal Manajemen Perhotelan, Vol. 4. No. 1. hal. 18-27 